\title{
Homelessness and Human Dignity in the City of Tshwane: An Encounter with Personhood $^{1}$
}

\section{Themba E Ngcobo²}

\begin{abstract}
Human dignity is a multifaceted, inter-disciplinary and cross-cultural topic in all ages. However, it has gained most interest and attention after the experiences of World War Two. In Africa (as with other countries), it is one of the most important questions to ask, especially in the era of post-colonialism. Africans should be able to define the question, "Who are we?" by looking through African lenses rather than repeating what has been described by the West. In this case, the vulnerable and marginalised people like the homeless of the City of Tshwane and of other cities should be given a platform on which they can make their contribution. The marginalised should be able to inform the prominent (or scholars) about how they view their situation as homeless people and how that translates into an understanding of human dignity. In this encounter, human dignity would be more contextually understood, explained and applied. Therefore, the task of the church would be to understand that human dignity is encountered as we meet and interact with people from different backgrounds, not a tag attached to personal achievements or success.
\end{abstract}

Keywords: Human dignity, Post-colonialism, African, Contextual Bible Study, Urban Mission.

\section{Introduction}

Human dignity is a multifaceted and sensitive topic, especially when one seeks to define and construct it on the basis of basic human experiences in South Africa. There are a handful of contributing factors towards that, which include urbanisation $^{3}$ and post-modernism, but apartheid is undoubtedly a chief culprit.

1 This article was published as a chapter in the peer-reviewed book Pavement Encounters for Justice: Doing Transformative Missiology with homeless people in the City of Tshwane (Mashau \& Kritzinger 2014), that was a result of the Meal of Peace Project of the Dept. of Christian Spirituality, Church History and Missiology at Unisa. The editors and the authors (as copyright owners), have given permission that this version may be published in Missionalia, as an accredited South African journal.

2 Themba E Ngcolo teaches Missiology at the Dept. of Christian Spirituality, Church History and Missiology. He can be contacted at ngcobte@unisa.ac.za

3 Urbanization, industrialization and globalization have contributed both positively and negatively towards developing countries such as South Africa. Pretoria News has reported that the City of Tshwane alone has more than 5000 individuals living in the streets (Monama 2014:1). Migrants from rural areas and surrounding countries move to the bigger cities in a search of 'gold', but unfortunately city life is contested space. It is the survival of the fittest. Life is too fast and busy, in such a way that individuals are only interested in themselves; and as a result, human dignity is bankrupted (Howe 1995:38). Some succeed to live an 
The apartheid system defined black South Africans as "semi-humans," while all the dignity was reserved for the "whites-only" population. When the whites of European descent who speak Afrikaans started to colonise South Africa in the 17th century, they introduced a theology which could underpin and foster colonialism: namely, a version of the theology of election and the covenant. This theology viewed Afrikaners as Israelites, as a volk that had been elected, called and led by the God of the covenant, and claimed that Afrikaners had supremacy in humanity and dignity, as beloved (or distinct) creatures of God (Mofokeng 1989:38-39). This was clearly affirmed by PW Botha, the apartheid-President from 1984 to 1989, as he addressed his cabinet on 15 August 1985 and declared that Pretoria was only for the white people. In this speech (as captured by a Sunday Times reporter) he stated: "The fact that blacks look like human beings and act like human beings does not necessarily make them sensible human beings. Hedgehogs ${ }^{4}$ are not porcupines and lizards are not crocodiles simply because they look alike" (Botha 1985).

This philosophy, however, was not only appreciated by the whites; there were even (some) blacks who started to accept that they were inferior and incompetent, and to view their blackness as a sign of weakness or wickedness. It is from this background that black theologians such as Biko, Buthelezi, Maimela, Mofokeng and others called for a new theological epistemology. Steve Biko who championed a "black consciousness movement", referred to Black Consciousness as an attitude and a way of life; a self-examination and self-realisation which would lead blacks to believe that, by seeking to run away from themselves and emulate the white man, they were insulting the intelligence of whoever created them black (Biko 1981:137). Black Consciousness called for a black self-definition rather than try to escape blackness. Takatso Mofokeng would describe this as an (African) theological anthropology, as the blacks seek to re-affirm their identity as image of God (Mofokeng 1989:44).

The question of who defines human dignity can by no means be avoided in this research; for the one who defines it is the one who owns it. There is an ultimate power handed to a person who adopts a describing role;

aspiring life, while those with shattered dreams remain the dwellers of the streets. They find their comfort and home on the pavements of such cities, as they live on the margins in the heart of the city. And it is in such homes (streets) that these residents have their dignity and rights trampled upon. They are exploited, raped (both genders), insulted and other inhumane things are performed on them against their will.

4 These words express the rationality of the Apartheid ideology, as they consciously treated blacks as lesser beings. These words are even more meaningful today, since this year (2014) South Africa celebrates 20 years of the so-called "freedom." Blacks are still the most oppressed and poor. And even though today we find white beggars, homeless or living in shacks, it does not equal the number of blacks who suffer the same fate. It has gone too far, so that when a white person begs for food, it is blacks that feel more pity for him than the other suffering black person, as if misery is a black inheritance. 
for naming and describing have a lot to do with authority, privilege and responsibility. ${ }^{5}$ As much as we would engage some scholars on this topic as we seek their understanding, we will be very critical of their approaches, for their power positions inform their findings and conclusions. As a result, this article seeks to adopt the approach to define human dignity from below, since in most cases topics like this are defined from the top, as the privileged and most powerful prey on the disadvantaged and marginalised. We will therefore compare the ideas of both scholars and ordinary readers of the Bible, with the aim of learning from the "street-side theology."

This chapter is an exercise in encounterology: a critical reflection on transformative encounters between people whereby trained readers of the Bible encounter ordinary readers. This engagement took place at Tshwane Leadership Foundation (TLF) in Pretoria, next to Burgers Park. In this set-up, a group of homeless men and abused women reflected on human dignity on the basis of Genesis 1:26-27. This encounter promoted the ordinary reader as the teacher and expert, while the trained reader remained a student, as they jointly interpreted Genesis 1 and other relevant texts, e.g. Psalm 8:3-9 \& Psalm 139:14-15. The facilitator (a trained reader) created a safe space for discussion and interaction, and the participants then championed the dialogue. The field was wide enough, so that the ordinary readers could engage in a discussion in interpreting, explaining and applying a Biblical text. The homeless and undermined individuals provided their own (original) interpretations of the text, in relation to their African and urban experiences.

As we seek answers to understand human dignity, we will (1) define the methodology used (2) seek to define human dignity (3) provide an encounterological reflection on the text and human dignity, and then (4) conclude by making a comparison between the understanding of scholars and homeless participants. In the conclusion, we shall be trying to find out if there were any new insights that emerged from the encounter.

\section{Research Methodology}

In this chapter a facilitator (who is also the author) adapted the Contextual Bible Study (CBS) approach, developed by Gerald West. The CBS is an adapted version taken from the manual compiled by the $\mathrm{Ujamaa}^{6}$ Centre for Biblical and Theological Community Development. The facilitator employed this action

5 It is our tradition as human beings that subconsciously parents or grandparents give a name to children, owners name their pets, a ruling government changes the names of cities and their streets, and in the same way, our neighbouring country Zimbabwe was the Republic of Rhodesia during the colonial era. Thus, authority and power belong to the one who names.

6 Doing Contextual Bible Study: A Resource Manual. Ujamaa Centre for Biblical and Theological Community Development and Research. 2011. 
research methodology as he facilitated this study at TLF on 3 July 2013. In this set-up, at least twenty (20) participants of both genders, South African as well as people from neighbouring nations, volunteered to take part. It is also worth mentioning that all of the participants were black Africans; thus, the findings of the process reflect an African indigenous understanding of human dignity.

This encounter had at least seven (7) steps. Step one (1) involved singing at least two songs with the participants and a prayer. Step two (2) was an "ice-breaker", as everyone introduced themselves by stating something good about themselves; the facilitator then led as he introduced himself first and the group became very excited about saying something good about themselves. Step three (3) dealt with Question 1: What is human dignity? This question was written on newsprint and displayed so that everyone could see it. Since this was an open question, the group did not divide into small groups. They gave their own thoughts and understanding. The response was good and the participation very interesting. The group then discussed their responses, and the whole group interacted with questions and answers. The facilitator merely guided the whole exercise to keep the discussion channelled.

Step four (4) dealt with Question 2: What is your view on evolution? This question was designed to allow the participants not to be limited or one-sided, since the facilitator was a theologian, which by default might hinder the participants from exploring their own understanding and other faculties in describing human dignity. In Step five (5), the group divided into four small groups to engage with Genesis 1:26-27. The participants read this passage in different versions and one of the members read in Afrikaans, after which she asked whether she could pray over the Word of God. She was then granted the request. Step six (6) was the groups' report-back on their discussions. As they presented their findings, a facilitator allowed the groups to ask questions of one another's presentations or to explain their concepts, if there was a necessity for clarity. In Step eight (8), the participants drew up a plan of action, suggesting what should be done to maintain the ideal of human dignity.

\section{Theological Reflection on Genesis 1:26-27 and human dignity}

This topic of human dignity is not a new discovery. It has been part of the Christian tradition for centuries, but it has gained popularity and momentum since the end of World War Two. A handful of scholars across the globe have provided valuable contributions on how we should understand it. It is also true that this topic is inter-disciplinary and cross-cultural. Therefore, we need to clarify from which perspective we approach it. We will, therefore, be looking at human dignity from a Christian and biblical 
perspective and try to (missiologically) contextualise it into a South African context. In this section we will engage with scholars and textual materials as we seek to discover human dignity.

To begin with, we are informed that "the English word dignity, rooted in the Latin, dignus/dignitas, means "worth of esteem or honour" (Siddiqui 2007:51). It is human worth, importance or value. Today, human dignity is classified under and within the boundaries of human rights. This owes its origin to the 1948 United Nations' Universal Declaration of Human Rights. In this declaration, Article one states that, "All human beings are born free and equal in dignity and rights. They are endowed with reason and conscience and should act towards one another in a spirit of brotherhood." As much as human dignity appears first in this declaration, however, it is still described by human rights. Even the Constitution of the Republic of South Africa (Act No. 108 of 1996) [as endorsed by other countries as well] includes human dignity in its Bill of Rights. The Constitution (only in Chapter 2.10) states that all human beings have "inherent dignity and the right to have their dignity respected and protected." But rights cannot be prerequisites for human dignity; human dignity should inform human rights. Vroom (2007:48) argues that:

Inherent dignity is not attributed or granted by the arbitrary decision of a community, but is recognised. Rights are accorded by law to people, but not human dignity - it is precisely the other way around, as dignity is the basis of rights. Dignity is also not something that can be inherited, but is a value that we acknowledge as such.

Rights can only be protected when human dignity is recognised, not the other way around. Human dignity is thus the safeguard of human rights.

\section{Human Dignity as a Part of the Whole}

Human dignity cannot be explained, apart from a creative act of God in totality. Biblically speaking, human beings are part of nature (Douglas 1996:721). Hence, human dignity should find its substance and significance in its inter-connectedness with the creation activity as a whole; for when human beings came into existence in the world, it was already occupied (by numerous species). The planet earth and its dwellers preceded the creation of humans. Therefore, human dignity should also refer to the value of creation as a whole; and thus "it is [or should also be] the dignity of creatures" (Webster 2007:22). As a result, to endorse human dignity is an endorsement of the dignity of creation as a whole.

Human beings find their sense of being through being part of the community; human dignity is therefore communal. It is rooted in living and sharing space. Acceptance and tolerance is a shared obligation; as a result, being a human is being with others (Howe 1995:37). We are born into 
community and for community. Thus, to be human refers to (1) a God-directed existence, (2) to be neighbour-directed and (3) to dominate nature (Berkhof 1971:24-31). Nature and community sum up a collective human dignity; for human dignity is shared and lived, hence not offered.

Human dignity is "not earned and does not rest on prizes or the respect that one has earned" (Vroom 2007:48). Human beings maintain their original, created nature (image of God) intended by God, regardless of the condition in which they now find themselves (Howe 1995:24). In the New Testament, Jesus defended the status, worth and dignity of Zacchaeus, owing to the fact that he is part of the whole (a member of Abraham's family line), even though he was not regarded as acceptable by the spiritual leaders of the time (Luke 19:1-10). Dignity is encountered, not simple ascribed or credited; it is encountered in such a way as to be beyond manipulation (Webster 2007:19). It is never determined by class, race, region or religion. It is owned - or perhaps shared - by a community; therefore, before rights are considered, human dignity must have been realised. Sharing, power and responsibility are as a result communal. Howe (1995:37) argues: "Dominion is linked to community and cooperation with God, humanity and creation as it is the conjoining of authority, power, wisdom and goodness; for when power is alienated from goodness, dominion becomes rape."

Human dignity as a collective dignity should be more embracing of uniqueness and individuality, as the community is made of collective individuals. Human dignity can only find its place within a community (Vroom 2007:48). At least, this is how Ubuntu ${ }^{7}$ has understood human dignity. For Ubuntu upholds human dignity and life in their totality, belonging to humanity as a whole. Ramose (2005:37) argues that Ubuntu should be understood as ubu-ntu of which the pre-fix ubu means becoming; therefore, Ubuntu is be-ing human (human-ness). Koopman (2007:183) supports this view by stating:

True humanity is not defined by independence and rationality, but by the willingness to enter into relationships with others... In the interaction with others, in the communion, in the relationship, I find my essence and being. I receive my being from the other. We receive our existence from the hands of the other and my existence is meaningful because there are others who want to share their existence with me.

7 Umuntu ngumuntu ngabantu is normally translated as, "A person is a person through others", but I would suggest that this translation sounds Western. My suggested translation would be, "A person is a human through others", for if a person shows humanity he/she is referred to as having Ubuntu. 
This Ubuntu idea of a collective dignity is shared by the Biblical view. The Bible affirms that life belongs to the community and our communality is rooted in the fact that God himself is community. Berkhof (1971:26) argues that: "God is not a solitary being, and a man created in his image is not at home in solitude. Man as an isolated unit cannot express the image of God. He can only represent this image in conjunction with others, as a man in fellowship."

Our-self-reflection of personhood should be defined in the context where individuals are interconnected with others, which is the Christian understanding of the Trinity. The Triune God (three persons in one) can only be understood as interdependent, unless we end up having the God of the Old Testament, the God of the Gospels and the God of the Acts of the Church. Koopman (2007:180) adds:

We have dignity because we are created in God's image; we have dignity because God became human in Jesus Christ and redeems us; we have dignity because the Holy Spirit, as God at work in the world, is actualising in and through us the new humanity that is a reality in Jesus Christ... This teaches that all humans do have dignity. Our dignity is an imputed dignity. It is an alien dignity which comes from God. And because it comes from God, it is inalienable.

The credentials of human dignity are embedded in the existence of God as Trinity. The Trinity works together (as a community) in sustaining human dignity; this proves the accountability of God in humanity. Human dignity is thus valued by God; and in community we should strive to maintain dignity.

\section{Human Dignity as God's Reflection}

In Judeo-Christian theology, the starting point for understanding what it is to be human is the affirmation that human beings are created in the image of $\mathrm{God}^{8}$ (Howe 1995:27). This view is based on Genesis 1:26-27. This passage argues that the first humans were created (bara) or made (bana) by God in his own image (selem) and likeness (demuth) as a potter creates or forms (yasar) out of the dust of the ground (adama) (Douglas 1996:13\&348; Howe 1995:28 \& Fichtner 1977:32, 34). The name Adam (adam) itself does not refer in the first place to a man (a person of the male gender) but has a stronger connotation of "mankind" or "humanity" as created beings taken from the adama (the ground) (Douglas 1996:13). The name Adam affirms the creative act of God in forming humanity. Therefore, both genders were and are created in equality to bear and reflect the image and likeness of God without distinctions. Vorster (2010:601) adds:

8 For the purpose of this article, we will avoid dwelling on the distinctions between the Jahwist and Priestly traditions in the Hebrew Bible (Genesis 1-2:3 and Genesis 2:4-25). 
People are created in the image of God and therefore are of equal worth. The relationship between male and female serves as a good example. The fact that the female was created with less physical strength than the male does not suppose an unequal relationship between them, because all humans are the image of God, despite differentiated characteristics.

Human dignity owes homage to God. A human being's "nobility, dignity, and potentiality is realised primarily in his relationship to God" (Fichtner 1978:34). For there is a difference between the creation of man as an image (tselem) of God, as opposed to a molten image (masseka) from copper, gold or silver, and a graven image (pesel) carved from stone or wood (Douglas 1996:499). Human beings are specifically set apart from the rest of creation for three main reasons: (1) the image of God-bearers, (2) given dominion over all the animals and (3) the breath ${ }^{9}$ of God (Douglas 1996:13). This specification to the creation of human beings sets human dignity at a different standard from the rest of creation; and God is that standard.

The expression of "the image of God" seeks to describe "a specific relationship between God and humans" (Berkhof 1971:22), which refers to "humankind as God's property" (Vorster 2012:2). Any injustices against humanity are crimes against God; as human beings are the reflection of God (Biko 1981:137). Boff (2013:9) argues that the creation projects a mirror towards God in his Trinity, as it reveals God to Godself. Creation reflects the creative power of God, while human beings represent God's stature and glory; therefore humans' dominion on earth can only be justified by the mere fact that they reflect God's image.

This creative act of God is distinct from the rest of his creative activity. When he created trees, birds, fishes, crawling animals and beasts, he created them in their own kinds; but with human beings, he created them according to his own image and likeness.

\section{Encounterological Reflection on Genesis 1:26-27 and human dignity}

This section conveys a critical reflection among members of the homeless people at TLF (in the City of Tshwane) as they engaged each other on Genesis 1:26-27 and other relevant scriptures (e.g. Psalm 8:3-9 \& Psalm 139:14-15) and theories (e.g. Evolution). The participants contributed in open discussions as well as in group settings. Their contribution was based on how they understood the Scripture as they implemented it in their own context and how they would

9 Douglas (1996:13) states that human beings are also made unique by the breathing into their nostrils (nismathayyim) by God, as they became living beings (nephesh hayya). God animates the human body with divine breath. It serves as an affirmation of the ontological and sacred status of human life (Vorster 2007:366). 
define human dignity in their own terms. However, their very first engagement was the encounter of their understanding of human dignity; this was done even before the reading of any scriptural passage. It was interesting that they defined human dignity as being a "creature created by God, having self-respect, honesty, and (thus) avoiding taking any person at face-value."

In their homelessness, "dirtiness" and rejection by the society as lesser beings, they still believed they had value and worthiness since they have a Creator. They believe that they belong to God who created all, and that alone calls for self-respect and appreciation. They believed that their current situation and experiences do not define who they are. Therefore, they have something to contribute to the community as far as their lifestyle is concerned. They argued that human dignity (or dignity of self) has a lot to do with the way "we behave in the community." This dignity is not something to comprehend only within us; it is also what we are to appreciate in community members. When we respect our surroundings, we respect ourselves. Therefore, the way individuals behave should indicate that they are not isolated entities, but belong to the whole. Since we are born into a community, we should always understand that our action will impact the community, positively or negatively. We need to live a life that reflects "honesty, politeness and humbleness" towards others. That implies that we cannot use our current situations as an excuse to harm the next person. Being homeless does not mean that we should steal or endanger others to cover our needs. We should implement values as human beings in the community. According to the TLF members' understanding, human dignity would also refer to a life lived out of values.

For the TLF members, human dignity covers many aspects of a human life. Human dignity feeds the understanding of personhood as a reflection of God; which then translates into the value or the worthiness of each and every being. This results from the fact that human beings are created in God's image; they are promoted to worthiness regardless and irrespective of class, race, educational and economic status. Hence, no one should be "taken at face-value."

On the contrary, they are aware of the new(er) or recent developments of human understanding and particularly the contribution of evolution in this regard. In discussing the credibility of the Bible or Evolution, they believe that the two are distinct fundamentals. They argue: "Evolution is man-made and the Bible is the Word of God." They question the credibility of Evolution, as they state that it is just human "scientific thinking." They understand Evolution to claim that "we develop from apes, whereas the Bible declares that (1) God created both apes and human beings, (2) human beings are created in the image of God, (3) a human being was the one who gave a name to an ape and (4) human beings are the rulers and they dominate the created order, including apes." On this basis, they regard human beings are set apart from the rest of the creation. 
From their argument that human beings are set apart from the rest of creation arose at least five (5) themes: (1) "Human beings are God-like beings;" (2) "When God created other creatures He said a Word and when he created human beings He used the soil from the ground and breathed into his nostrils and a man began to breathe;" (3) "We are different because we know what is good and evil;" (4) "God made us a little lower than the angels and gave us authority over the rest of creation;" and (5) "Human beings are crowned with glory and honour." As a result, human beings are unique from the rest of the creation in intelligence and values. This setting-apart comes with a responsibility, since we have the accountability towards the whole creation as its guardians and stewards.

It was only from this stage that we started reading the Bible. However, the above information reveals the relevancy of the Bible to the group members. This reflects their upbringing from childhood or developmental stages. Their argumentation in some way pre-empted the whole exercise. For after the reading of the scriptural passages, they had to discuss in four (4) small groups how they understand the passages and were asked to re-define human dignity. They did not argue very differently from their earlier understanding before the Bible was read. Some statements were the same but formulated differently, e.g. the underlying theme in all groups was that the Scriptures declare that human beings are "created in the image and likeness of God." This understanding is similar to an earlier statement that suggests that human beings are "God-like beings." Human dignity assures humanity that they are like God. And because of this, Group four (4) strongly argued that "Genesis 1:26-27 fulfils human dignity;" therefore "we should then not look down upon ourselves, because we are superior beings." Their emphasis is that this entails that "God created every part of us as He put us together," as He formed us in our mothers' wombs. It is remarkable that none of the groups described the image and likeness of God on the basis of gender. To them, human beings (both male and female) are the self-reflection of God. Therefore, human dignity applies to everyone.

They also argued that human dignity means Ubuntu. In this context, Ubuntu does not just denote hospitality, but being an important member of the community. Ubuntu refers to self-understanding through the lenses of the community, as we maintain "self-discipline, self-respect and the way we behave in the community." The understanding of human dignity as Ubuntu on the basis of Genesis 1:26-27 would mean that we are empowered and authoritative individuals of the community. However, when the community rejects us, we should treasure the knowledge that, according to Genesis 1:26-27, "God chose us separately and God has a purpose for our lives, and even if we are currently go(ing) through tough times we should not lose hope, as He loves us." 


\section{Emerging Voices}

After analysing the transcripts, there was not much difference between scholars and ordinary readers of the Bible in understanding what the Scripture says about human dignity. To a large extent, they shared the same ideas but expressed them in different ways. They both dwelt on Genesis 1:26-27 in their attempt to describe human dignity, more than any other passage in the Bible. As much as the theologians tried to abstract human dignity from this text, ordinary readers believed that it expresses the essence of human dignity. This may either mean that the Bible is self-interpretative or that the ordinary reader's views have been influenced by theologians through the preachers, teachers and parents who have shaped their understanding since childhood in family prayers, Sunday school lessons and sermons.

However, the ordinary readers understand human dignity as Ubuntu. This is a great contribution to Ubuntology and the understanding of humanity at large. In most cases, Ubuntu is understood as an act of hospitality and kindness towards others; but to argue that human dignity is Ubuntu is to marry the significance of an individual with the rest of the community. In this understanding, Ubuntu does not victimise individuals or sacrifice uniqueness in the society, but appreciates them as key members of the whole. Ubuntu would then argue that we cannot be kind to the next person unless we first appreciate that they are valuable and important to God and the rest of the society. Ubuntu will therefore mean self-discovery or realisation as we respect our fellow human beings and nature; it enriches self-understanding as an inward look, and promotes communal involvement and participation as an outward expression.

In the TLF members' understanding of human dignity as Ubuntu, they employed the similar pattern of words as Ramose. They described human dignity and Ubuntu as politeness and humbleness, whereas Ramose (2005:37) states that Ubuntu is "a humane, respectful and polite attitude towards others." This expression contributes to a contextual understanding of the Bible, as human dignity based on Genesis 1:26-27 would be understood not from a Western individualistic view, but from a communal aspect. I find this more relevant with the text, as Adam was not complete without Eve. He needed another being to make sense; for Adam was "bored" and "boring" without his companion. But this does not suggest that Adam was less important; he is as important as Eve. Together, they reflect the glory and honour of God, irrespective of age, gender and class. Therefore, human dignity is God's bestowed image on be-ing - a being that cannot be taken away by any power or circumstance. 
However, the TLF members understand that human dignity should be an ongoing discussion, for it should be maintained or preserved in human thoughts as long as humanity exists. The following action plan was then suggested:

- Follow God against all odds.

- Persist in behaving in a dignified way that pleases God.

- Do not let anyone or anything define you.

- Focus on what you are doing and do what is good.

- Expect people to judge you but stick to what you know is right before God.

- Stand firm on who you are and what you stand for.

\section{Conclusion}

Human dignity should be viewed as the most prestigious virtue bestowed on humanity by God. This prestige should not be seen as a reputation or praise that arises from success or achievement; that could easily become an individualistic attitude which does not integrate the whole. This prestige should be aimed at what benefits our families, societies, country and the world at large. That would be what we could describe as Ubuntu. Ubuntu would then be understood as be-ing - a human being among humans and nature.

In this understanding of Ubuntu, human dignity will define rights, not the other way around. It will seek to view beings in a state of being human, an image and reflection of God, rather than possessions and individualistic accolades. In this view, human dignity would be the greatest gift given to humanity.

The Church should seek to emphasise that human dignity is encountered as we meet and interact with other people. This would promote appreciation and a welcoming of those we consider different from us. Therefore, the homeless, prostitutes, thieves, murderers, people of different religions and foreigners would be viewed as human beings before their financial state, race, class, gender, faith or regional background. It will only be then that we can jointly say with Paul: "There is neither Jew nor Gentile, neither slave nor free, nor is there male and female, for you are all one in Christ Jesus" (Gal 3:28 NIV). The fact that Christ died for all should be enough to move us to treat all people as part of the whole, with dignity. 


\section{Bibliography}

Berkhof, H. 1971. Man in Transit. Key Publishers: Toronto

Biko, S. 1981. Black Consciousness \& the Quest for a True Humanity. http://escholarship.org/uc/item/4fk5d8x3. [Accessed 04. Nov. 2014].

Boff, L. 2013. Christianity in a Nutshell. Orbis Books: USA

Botha, P.W. 1985. http://www.southafrica.to/history/Apartheid/PW_Botha/ Hoax_PW_Botha_speech_1985.htm. [Accessed 04 Nov. 2014].

Douglas, J.D. 1996. New Bible Dictionary. 3rd Ed. Inter-Varsity Press: England.

Fichtner, J. 1977. Man the Image of God. Alba House: USA.

Howe, L.T. 1995. The Image of God: A Theology for Pastoral Care and Counselling. Abingdon Press: Nashville.

Koopman, N. 2007. Some Theological and Anthropological Perspectives on Human Dignity and Human Rights. In Scriptura Vol. 95. Page 177-185. University of Stellenbosch: Cape Town.

Mailu, D. 1985. https://groups.google.com/forum/\#msg/batananiboys/ IxYM6mu3-dI/CriByvhVPQAJ. [Accessed 03 July 2014. 12:10].

Middleton, P. 2007. 'George Newlands: An Appreciation', in The God of Love and Human Dignity. Page 1-4. T\&T Clark: New York.

Mofokeng, T. 1989. The Cross in the Search for True Humanity: Theological Challenges Facing South Africa. Journal of Black Theology, 3(2).

Monana, T. 2014. http://pretorianews.newspaperdirect.com/epaper/ viewer.aspx, [02 June 2014].

Ramose, M.B. 2005. African Philosophy through Ubuntu. Mond Books Publishers: Zimbabwe.

Siddiqui, M. 2007. 'Between God's Mercy and God's Law: Human Dignity in Islam', in The God of Love and Human Dignity. Page 19-33. T\&T Clark: New York.

Vroom, H.M. 2007. 'The Dignity of 'I and Me", in The God of Love and Human Dignity. Page 19-33. T\&T Clark: New York.

Vorster, N. 2007. 'The value of human life', Ecumenical Review 59, 363-384, http://onlinelibrary.wiley.com/doi/10.1111/j.1758-6623. 2007.tb00638.x/pdf. [Accessed 06 June 2014]. 
Vorster, N. 2010. 'Are freedom and equality natural enemies?', The Heythrop Journal. A Bimonthly Review of Philosophy and Theology 51, 594-610.

Vorster, N. 2012, 'A theological perspective on human dignity, equality and freedom', Verbum et Ecclesia 33(1), Art. \#719, 6 pages. http://dx.doi.org/10.4102/ve.v33i1.719

Webster, J. 2007. 'The Dignity of Creatures', in The God of Love and Human Dignity. Page 19-33. T\&T Clark: New York.

Williams, D.T. 2013. Ubuntu: A Relational Theology of Humanity. Cluster of Publications: South Africa. 